\section{Libraries, Pharaonic Egypt}

KATHARINA ZINN

Despite previous doubts, a library system of a kind existed in ancient Egypt and included a variety of institutions that stored writings, along with their inherent knowledge, for various purposes. These are attested in more than three hundred textual and archaeological sources. Some can be classified as libraries, others as archives. These institutions and their responsibilities changed over time.

Although literature in the narrow sense did not exist until the Middle Kingdom, libraries were known before that time. It therefore follows that Egyptian libraries should not be understood in the modern sense - that is, as institutions carrying literary and scientific stock, and catering for a largely literate public with diverse tastes. The collected records of administration, bureaucracy, and temple-cult, as well as sacred, divinatory, and magical texts, were not meant for daily usage or pure enjoyment. These writings documented the progress of MAAT, the cosmic order of right routine and rules, and reflected the specific specialization of the library. Consequently, they held a specific position and fulfilled a particular function within this order. Superficially, ancient Egyptian libraries appear to correspond to our modern archives. In the view of the ancient Egyptians, however, their role went beyond mere storage of ongoing cases. This leads to the conclusion that these institutions functioned contemporaneously as libraries, especially before the New Kingdom. However, they were clearly distinguished from coeval archives. The library stock represented ongoing cases of the day-to-day business of bureaucracy and administration. Institutional overlap was possible. Both bodies could store similar documents, especially in minor (cult-)places.

We observe several terms for library and archive, whose differences and uses have to be determined. As to Egyptian idioms for

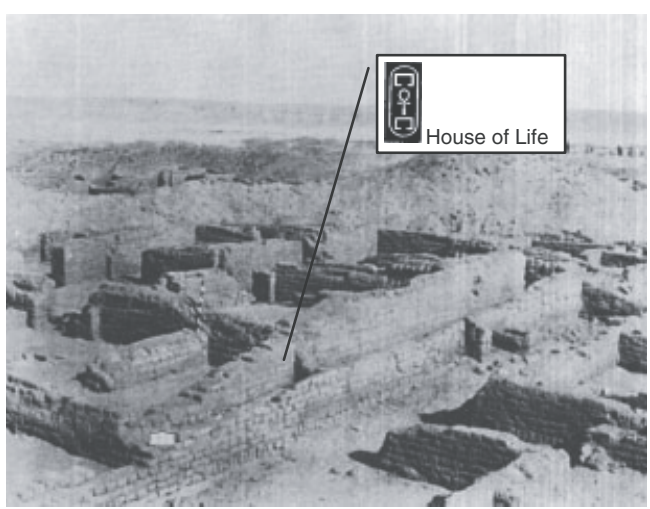

Figure 1 Remains of the "House of Life" in Amarna. After Pendlebury, The Central City and the Official Quarters: The Excavations at Tell El-Amarna during the Seasons 1926-1927 and 1931-1936 (1951, vol. II, photo in pl. XLIX and stamp in pl. LXXXIII). Courtesy of the Egypt Exploration Society, www.ees.ac.uk.

"library," we find per-medjat ("house of books"); per-medjat-netjer ("house of divine books"); per-medjat-netjer-per-aa ("house of divine books of the great house," i.e., pharaoh/palace); per-ankh ("house of life"); per-medw-netjer ("house of the divine words/ hieroglyphs"); per-( $n w)$-seshw ("house of writings"); khwt-jrjw ("house of ritual writings"); and js-n-seshw ("chamber/office of writings"). Some terms could be used synonymously. It is very difficult to find acceptable explanatory translations that show the differences and specific features of the individual institutions. All these terms are attested in different documents, and occur with diverse frequency and for varied periods. They are to be differentiated from the "archives": areryt (or aryt, areret; an administrative room/unit in the gateway/doorway of temples and palaces; a place to store legal documents); $j s-n$ kherj-khetemw ("chamber of the sealed documents"); jset ("chamber/office/archive"); per-a-neswt ("house of the royal records"); per-kherj-wedjeb ("unit for estate's administration including registry and archive"); kha-nseshw ("office writing hall/archive"); khenet/ 
kheneret-djeseret (a closed area, apparently used for storage of divinatory and administrative texts); khetem-n-pa-kher/pa-khetem (board of control: khetem as place of the legal council (kenbet), and where official/legal acts happen such as the reciting of official letters and degrees, registration of workmen - and necessary paperwork is stored); set-seshaw (actual archive rooms within the state chancellery - literally, "place of the letters of the pharaoh" - ta-set(naw)-shaswt-per-aa); and semayt (archive for documents concerning the administration of the palace, which might also include sacred writings).

The best-known word for a library was "House of Books" (per-medjat $\square,{ }_{\square}$ ). Together with per-medjat-netjer (house of divine books $\square \square \frac{\sim}{\sigma}$ ), this term was used from the Old Kingdom onward. The per-medjat was in existence from the 3rd Dynasty. As we have no literature or even longer texts from this period, this institution accords with the body we would define as an archive. Very soon it acquired subdivisions that are known from titles, especially connected with the knowledge of building pyramids and temples. During the Middle Kingdom, per-medjat was used synonymously with other terms such as per- $(n w)$ seshw. Being in fact a small library, exclusively used in the daily cult-ritual, the "House of Books" could be understood as an image of an ideal larger library on the mythological level within the idea of the "temple as world."

Similar to this, the term "House of Life" (per-ankh $\square$ f $\square$ ) was used in parallel with the expression $j s-n-\operatorname{sesh} w$ in a dedication inscription of Rameses II on the first pylon of the Luxor Temple. While the "House of Books" is to be seen as a small special library, built directly in the inner temple, the "House of Life" was not a library but a kind of academy attached to temples within the temple precinct or close by, which included a large library. These buildings were made out of mud bricks, in contrast to the stone rooms of the inner temples. The per-ankh was associated with (divine) kingship and functioned as a place where cultural knowledge was created, used, and preserved. Although the "House of Life" is well attested in writing from the end of the Old Kingdom onward, we have only one archaeologically confirmed, undisputed example, in AMARNA, proved by stamped bricks bearing the hieroglyph per-ankh. This could not be seen when the building was intact, but came to light during the excavation. Interestingly, this per-ankh was located close to the state chancellery (ta-set-(naw)-shaswt-per-aa), where the correspondence of the pharaoh was stored, showing their difference in purpose.

The few known temple-libraries, built in stone, are small special libraries exclusively used in the daily cult-ritual. In EDFu, the only $2 \mathrm{~m}^{2}$ per-medjat is situated in a niche in the eastern wall of the pronaos. No papyri were found, but the walls were inscribed with a book catalogue and decorated with scenes of book-chest offerings to Horus-Behedeti. Niches in the east and west wall seem once to have been furnished with book chests. In PHILAE, the permedjat is situated in the East Colonnade of the Isis Temple Forecourt. There are only a few relief blocks known from the library of the Mont Temple in El-Tôd, possibly located at the rear of the temple. In Tanis (see TANIS, SAN EL-HAGAR), a French excavation brought to light a brick building containing traces of papyri, sherds of limestone, and other fragmentary objects. This building could be either an archive or a library. Furthermore, another French excavation in the Ramesseum excavated small rooms, perhaps once used as offices, between the palace and the northern repository, identified as per-ankh.

SEE ALSO: Archives; Priests and priestesses, Egypt; Science, Egyptian; Scribes, Egypt; Temples, Pharaonic Egypt.

\section{REFERENCES AND SUGGESTED READINGS}

Budde, D. (2000) Die Göttin Seschat. Leipzig.

Burkard, G. (1980) "Bibliotheken im alten

Ägypten.” Bibliothek 4: 79-115.

Gardiner, A. H. (1938) "The House of Life." Journal of Egyptian Archaeology 24: 157-79. 
Nordh, K. (1996) Aspects of Ancient Egyptian Curses and Blessings: Conceptual Background and Transmission. Uppsala.

Zinn, K. (2008a) "Bibliotheken im Alten Ägypten.” $\mathrm{PhD}$ diss., University of Leipzig.

Zinn, K. (2008b) “Tempelbibliotheken im Alten Ägypten.” In H. Froschauer and C. Römer, eds., Spätantike Bibliotheken: Leben und Lesen in den frühen Klöstern Ägyptens: 81-91. Vienna.

Zinn, K. (forthcoming) "Temples, Palaces and Libraries - a search for their alliance between archaeological and textual evidence." In K. Spence and R. Gundlach, eds., Fifth Symposium on Egyptian royal ideology: palace and templearchitecture, decoration, ritual. Wiesbaden. 